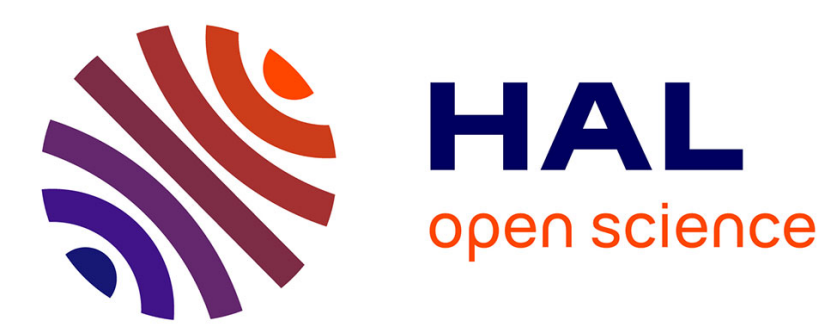

\title{
Horacio Vaggione: Towards a Syntax of Sound Jean-Claude Risset
}

\section{To cite this version:}

Jean-Claude Risset. Horacio Vaggione: Towards a Syntax of Sound. Contemporary Music Review, 2005, 24 (4-5), pp.287-293. 10.1080/07494460500172113 . hal-00096673

\section{HAL Id: hal-00096673 https://hal.science/hal-00096673}

Submitted on 12 Jun 2020

HAL is a multi-disciplinary open access archive for the deposit and dissemination of scientific research documents, whether they are published or not. The documents may come from teaching and research institutions in France or abroad, or from public or private research centers.
L'archive ouverte pluridisciplinaire $\mathbf{H A L}$, est destinée au dépôt et à la diffusion de documents scientifiques de niveau recherche, publiés ou non, émanant des établissements d'enseignement et de recherche français ou étrangers, des laboratoires publics ou privés. 


\section{Horacio Vaggione: Towards a Syntax of Sound}

Jean-Claude Risset

This article stresses the important contribution of Horacio Vaggione to inserting the computer within a musical project. The theoretical contributions of Vaggione shed light upon the way he takes advantage of the computer in his musical activity-not merely for problem solving, but rather as a component of a complex system which intervenes in a genuine polyphony of processes involving a multiplicity of time scales. His musical works evidences concern and imagination concerning morphology: he builds sturdy structures from minute grains. His music reveals novel figures: while bringing to the ear a world made up of atoms, it manifests the arrow of time.

Keywords: Computer Music; Fractals; Granular Synthesis; Vaggione, Horacio

Horacio Vaggione's approach is striking in its originality and coherence. He is one of the first composers to have completely integrated informatics into his compositional process. His theoretical writings illuminate his musical intentions taking into account the computer's possibilities in a concerted way. The role he gives to the computer is not ancillary, neither is it ideological, a simple tool or a substitute for thought. For him, the computer is a laboratory, as material as it is intellectual, a partner favouring the emergence of irreducible musical situations by using elaborate interplay. Vaggione's prolific work is a powerful and eloquent example of what computerassisted musical creation can be.

Hugues Dufourt (1991, pp. 332-333) describes the renewal of music stimulated by the computer in the following way:

Music has changed scale, changing in turn its language.... Sound is now considered in terms of new dimensions and relationships. Spectra, phases, transients, intensity, brilliance, factors of fusion and segregation are now composed. The relationships between the constructed and the perceived, between quantity and quality, are renewed.... In this way, music of the last twenty years has furthered the century's momentum. Today, music has reached a dialectic between categories of infinitely small sound parameters, achieving in ways that 
are clear and specific to itself, an art of timbre prefigured by Debussy and Schoenberg.

\section{Horacio Vaggione's Approach}

Vaggione sets out from digital potentialities: anything can be represented as digits and thus adapted through the logic and various treatments provided by computer programming. This leaves no hiatus between synthesis and sound treatment. Uniting the computer's paradigmatic capacities with digital sound coding allows both material and structure to be treated similarly, which paves the way for a genuine sonic syntax. For Vaggione, composition no longer involves a choice between an instrumental medium and a technological medium: moreover, his opus of works, be they instrumental, mixed, interactive or for tape, all testify to similar preoccupations-extending instrumental performance into the digital realm or transposing digital concerns into the instrumental realm. By bridging gaps between traditionally disconnected spheres like material and structure, or vocabulary and grammar, informatics creates a continuum between microstructure and macrostructure. It is no longer necessary to maintain traditional distinctions between an area exclusive to sound production and another devoted to structural manipulation on a larger temporal level. The choice of granulation, or of the fragmenting of sound elements, is a way of avoiding mishaps on a slippery continuum: it permits the sorting of elements within a scale while it allows individual elements to be grasped. The formal concern extends right into the microstructure, lodging itself within the sound grain.

Dufourt has defined with perspicacity the mutations imposed on music by the industrial and technological revolutions: many of his remarks apply perfectly to Vaggione's approach and theoretical positions. In the following excerpt, he incites us to

focus on the infinitesimal. The microscopic details of sound that technology brings within reach of the human ear become a subject of conscious stimulation and can, in their most subtle variations and elusive transitions, provide the substance of refined art. For, material based in some way on the objective ambivalence between sound and noise encourages interaction within this contradictory relationship, creating wholly new tensions. The state of being in contrast that makes the condition of music possible is not abolished but rather displaced and profoundly modified. The musical domain is no longer defined by its being in opposition to the sonic domain in general, but instead by its capacity to integrate a set of determinants, both complementary and contradictory, into a theoretical organisation. (Dufourt, 1991, p. 297)

Vaggione has been explicit about his own musical strategies. His theoretical thought addresses musical composition's fundamental problems and its ongoing relationship with computer technology. The computer is not considered as a tool for solving clearly defined problems, but as a component of complex systems. ${ }^{1}$ 
Composition is therefore envisaged as a complex system characterised by a specific internal interaction. Informatics enables the articulation of different levels and scales of time, even as it maintains a continuity between sound synthesis, sound processing and the generation and manipulation of musical structures. ${ }^{2}$

Sound does not come of itself, it has to be articulated and organised into figures. Constructing from sonic material is not enough, for the material itself has to be constructed. Vaggione works 'beyond the symphonic realm'. Rather than combining timbres, he composes the sound material 'directly', thanks to 'musicalised electricity' since the computer, at last, allows syntactic activity to be extended towards the realm of the sound and compositional activity to be performed on a microstructural level. Working on sound is already a morphological process: it acts 'not only on parametric variables, but also on saliences, and not only on single elements, but also on compounds-multi-articulated entities with specific formal properties' (Vaggione, 1996).

Vaggione refuses to dissect music into sound objects in Schaefferian terms (Schaeffer, 1966). Composition should not rely on juxtaposition, it should superimpose different processes into a sort of polyphony. Beyond the distribution of sounds in time, time itself has a role to play within sound, vivifying it, unfurling it, imprinting it with a scale, shaping it, deforming it as in a mirror. The composer has to take a multiplicity of scales into account and provide connections between noncongruent temporal dimensions. Even if time must still be composed, temporalities 'to be composed' are plural and non contradictory: a 'syntactic time' must articulate them into a form. ${ }^{3}$

It is crucial to Vaggione that the local context, singularities and the carrying out of figural work remain important. The objective is to produce, coordinate and contrast single events, and not to govern the successive by global laws. This excludes the stochastic perspective; mass criteria are not relevant. Transformations modify singularities without loosing them. They can be re-composed: both the repeated folding of a baker's dough and the plying of Smale's horseshoe tend towards chaos even as they preserve quasi-periods and ceaseless returns. This concern with constructing a musical syntax capable of assuming different levels of discontinuity, non-linearity, exceptional events and figures that channel energy, information and identity is central to Vaggione's musical problematic: a multiplicity that must be articulated without compromising control or the global context.

What is at stake in musical research ${ }^{4}$ extends far beyond the confines of sound representation. It is concerned with modes of presentation and incarnation. In particular, the morphological transformations brought about through analysissynthesis become a significant arena of conception and creation. Vaggione refuses a unitary vision that could only be simplistic. His theoretical reflection casts direct and innovative lighting not only on the author's creative processes, but also on a whole branch of contemporary creation incorporating the computer. His texts subtend his compositional activity and clearly explain his personal choices. Even beyond the subjectivity of his own choices, they offer an important contribution to today's 
musical thought and some of the most pertinent literature on computer music. They elaborate the dialectics between material and structure, object and syntax, and the relationships between networks, scales and form. They affirm his in-depth personal knowledge, along with his largesse of vision, maturity and welcome aloofness from any fascination with effective but simplistic means and from blind-deaf submission to any given theory.

Vaggione was one of the first to introduce fractals into music. Only too conscious of music's richness and specificity, he was not one to be taken in by the musical limits of the important idea of self-similarity. In his theoretical texts, we find very pertinent remarks on the notion of complexity, on the relationship between synthesis and notation, and on the local, 'regional' character of ontologies. We also find explicit criticism about how stochastic music and the theory of information prove ineffective in articulating multiple levels, and a welcome revival of the notion of the object. For Vaggione, composition implies a network of objects, but not sound objects in the Schaefferian sense: these would be opaque and difficult to manipulate. What he proposes is a dynamic definition of the object as a complex ensemble rather than as a basic block, a structure that can be transformed and integrated into a network, an operative category related to the concept of object programming in computer languages.

\section{His Music}

As original and important as Vaggione's theoretical texts are, they remain, as has been remarked by Marta Grabócz, somewhat opaque. While concerns presented in the texts do clearly appear in his works, the texts remain distant, offering few precise indications about these works and how these works are made. They hardly allow us to even imagine or anticipate them. Vaggione states that several levels of comprehension are possible, and that only the composer can be certain of the precise genesis of a work. Yet he wants his music to speak for itself and denies any subordination or justification from any other discipline outside itself. Jean-Toussaint Desanti, philosopher of mathematics, refused to concede a privileged point of view to philosophy; rather than pursuing a totalitarian dialectic, he exemplified a specific mathematical approach that can only be proven from its own inner logic (Desanti, 1975). Similarly, Vaggione (1996), insisting that music is irreducible, evokes Wittgenstein who speaks of the singularity of a musical work as the 'solution' to a problem that is unidentified-except in specifically musical terms. The musical validation of multi-scale constructions requires an action/perception feedback loop; it can only be achieved through real or 'inner' listening.

Works like Octuor, Fractal $C$ and Thema boldly introduced new paradigms of sound syntax and are already classics. In Thema, for bass saxophone and tape (1985), sound material derived from instrumental playing techniques-'clouds' of key noises in particular-are transformed by specific non-linear distortions and convolutions with other sounds. Elsa Justel (2000) describes this work as 'a kind of woven sound, 
brocaded with irregular threads'. Though genetically modified, the material remains anchored perceptually due to the continued presence of energetic characteristics. Vaggione often uses these kinds of morphological variations from 'micro-time' to 'macro-time'. Working with sound at a microscopic level introduces all sorts of hitherto unheard designs.

The piano has often served as a laboratory for the composer, allowing him to put his newly imagined modalities to the test. Thus, Vaggione's compositional processes are revealed through his piano music. In Tahil and Myr, for solo piano, objects are put into motion and dialogue from changing perspectives. In Till and Leph, piano timbre is prolonged and amplified, encrusted with sound crystals, sprinkled with gleaming powders and particles, but the electronic sounds are never merely decorative, they make the quicksilver flux and moving structures visible.

Vaggione's music, like that of François Bayle, displays morphological inventiveness (see Bayle, 1993). It exposes, reveals or symbolises meteoric or mineral events in sound, as if composition were rediscovering the physics, mechanics and vibratory means of creating sound. It often begins with a rather brutal impulse, a disruption, a kind of explosion, followed by the emergence of a kind of resonance or after-effect that behaves in a more sustained way. A succession of events like this brings to mind the connection that exists in the physical realm between the random behaviour of a dissipative linear system and this system's reaction to a stimulus or response to a restriction. Every physically realisable system is causal: effect can never precede cause, time is irreversible. This condition leads to a relationship expressed by a precise mathematical formula linking the real and imaginary components of the system's complex impedance, or if you wish, between its resistance and the fluctuation of its inherent forces.

The so-called 'Callen and Welton theorem' precisely relates susceptibility, overall resistance, to fluctuations in the linear system (Callen \& Welton, 1951). Though it may seem somewhat abstruse, this mathematical theorem yields in certain physical situations well-known and important formulae. Thus, Nyquist's formula relating to the background noise produced by voltage fluctuations of electric terminals, depending on their size, is a particular case of the Callen and Welton relationship. The same rules also govern Brownian movement, Planck's law of radiation and Mandelstam's dispersion relations in nuclear physics. Is this a conscious or unconscious metaphor for Vaggione? Probably a sharp awareness of irreversibility and its consequences. The objects proposed in digital music are susceptible to a systematic and (thermo)-dynamic analysis-into which Ilya Prigogine has introduced the concept of order through fluctuation.

In both his theoretical writings and his works, Vaggione accepts complexity, the articulation of multiple levels, without permitting any loss of detail or singularity. He is at the same time looking for coherence. Costin Miereanu refers to the intensity of Vaggione's aesthetic quest in regards to the development of technologies. Vaggione longs to add and disclose new objects— his art leaves no room for nostalgia: 'Never desire, Nathanaël, to taste again the waters of the past'. ${ }^{5}$ 
Rigorous workmanship can never fully guarantee a musically coherent result. The strong desire for a reticulated approach, a multilevel composition of object networks could forebode a chaotic result. Perception has to validate action. As we know, impressions of the physical presence of sounds well up from within us, from our inner space where they are free to fly: our brain infers their trajectories from clues transmitted by sound signals. Even though Vaggione calls perception the ultimate criteria, one could argue that he is only evoking the problem of perception in a tangential way, that he is not overly preoccupied with references or similarities. Some of his works may be thought too dense, too complex or too 'rushed', but they can hardly be denied their equilibrium, their form, their appropriation of ideas to materials and their resolute articulation of the complex multiplicity they engender. Borges wrote 'The Book of Sand'; Vaggione fashions solid musical constructions out of slender, pulverised and intangible material.

Horacio Vaggione's musical vivacity is mercurial: boiling, turbulent, intense, urgent, effervescent, crystalline pulverisation, disintegrating light dust, hardly ever at rest. In Atem or in the Préludes suspendus II, even moments of calm reveal a mysterious, minuscule and almost imperceptible activity. Music imprinted with a sort of feverishness, ${ }^{6}$ radiating shimmers, flashes and flares, and ceaseless scintillation. As if wanting us to hear a universe of atomic particles. ${ }^{7}$ Shifting, dynamic musicmusic that manifests the arrow of time.

Translation by Jacqueline Rose and Jeffrey Grice

\section{Notes}

[1] Complexity understood here, in the sense given to it by Jean-Marc Lévy-Leblond, as belonging to systems in which a mutual interplay between different levels is demonstrated.

[2] Vaggione refuses to make pitch into a taboo, as is often the case in electronic music. However, his concern for unity does not go so far as to accept the continuity that Stockhausen promulgated between audio and sub-audio frequencies, pitches and duration-a continuity more theoretical than perceptual.

[3] In 1953, Jean-Etienne Marie (1953, p. 113) was already defining rhythm as 'a combination perceived by the intellect, of the diverse meters produced by the repetition of any element'.

[4] In this respect, it should be mentioned that Vaggione was the first academic in France to be nominated to a computer music position at university level. He directs a highly motivated group at Paris VIII. Both Anne Sedes and Antonio de Sousa Dias work there, as well as outside researchers like Daniel Arfib and Curtis Roads.

[5] A. Gide (1897), Les nourritures terrestres: 'Ne désire jamais, Nathanaël, regoûter les eaux du passé.'

[6] A character evoking the instrumental works of the late Jean-Pierre Guézec.

[7] The atom of sound, however, does not exist, even though granular analysis seems to suggest it. The sine wave, the grain or the wavelet are only convenient intermediaries with no intrinsic necessity or reality. A sound can remain audible even on an atomic scale-one can detect sounds causing vibrations of the eardrum smaller in amplitude than the dimension of a hydrogen atom: but if the molecules in air vibrations could be seen, we would only observe chaotic trajectories. 


\section{References}

Bayle, F. (1993). Musique acousmatique: propositions ... positions. Paris: INA-GRM/Buchet-Chastel.

Callen, H. B. \& Welton, T. A. (1951). Irreversibility and generalised noise. Physical Review, 33, $33-40$.

Desanti, J. T. (1975). La philosophie silencieuse. Paris: Editions du Seuil.

Dufourt, H. (1991). Musique, pouvoir, écriture. Paris: C. Bourgois.

Glansdorff, P. \& Prigogine, I. (1971). Structure, stabilité et fluctuations. Paris: Masson.

Justel, E. (2000). Les structures formelles dans la musique de production électronique (Doctoral dissertation, University Paris 8). Villeneuve d'Ascq: Presses Universitaires du Septentrion.

Marie, J. E. (1953). Musique vivante. Paris: Presses Universitaires de France.

Risset, J. C. (1996). Composing sounds, bridging gaps: The musical role of the computer in my music. In H. de la Motte-Haber \& R. Frisius (Eds), Musik und Technik (pp. 152-181). Mainz: Schott.

Risset, J. C. (1996). Calculer le son musical: un nouveau champ de contraintes? In H. Dufourt \& J. M. Fauquet (Eds), La musique depuis 1945: matériau, esthétique et perception (pp. 267 - 283). Sprimont: Mardaga.

Risset, J. C. (2003). Illusions musicales. Pour la Science, 39, 66-73.

Roads, C. (2002). Microsound. Cambridge, MA: MIT Press.

Schaeffer, P. (1966). Traité des objets musicaux. Paris: Editions du Seuil.

Vaggione, H. (1995). Autour de l'approche électroacoustique: situations, perspectives. In Esthétique et Musique Électroacoustique, Actes de l'Académie Internationale de musique électroacoustique, Vol. I (pp. $101-108$ ). Bourges: Éditions Mnémosyne.

Vaggione, H. (1996). Composer avec des réseaux d'objets. In Composition/Diffusion en Musique Électroacoustique, Actes de l'Académie Internationale de musique électroacoustique, Vol. III (pp. 182-186). Bourges: Éditions Mnémosyne.

Vaggione, H. (2001). Some ontological remarks about music composition processes. Computer Music Journal, 25(1), 54-61.

Vaggione, H. (2002). Technologies, conjonctures et supports de la musique. In Composition et technologie en Musique Électroacoustique, Actes de l'Académie Internationale de musique électroacoustique, Vol. VI (pp. 164-169). Bourges: Éditions Ménomosyne. 